\title{
Drastic lay-offs loom at NASA headquarters
}

Washington. The US National Aeronautics and Space Administration (NASA) announced last week that it is to cut its headquarters staff by half over the next 18 months, a move that is expected to lead to the first forced lay-offs in more than 20 years.

The decision suggests that NASA is taking seriously new five-year budget projections handed down by the White House last month, despite recent public assurances by Daniel Goldin, the administrator of the agency, that the figures are not cast in stone.

In a memorandum to employees, Goldin cited "increasing budget pressures" as his reason for instructing the agency's Washington headquarters to reduce its staff from 1,400 to between 650 and 700 by 1 October 1997. NASA managers have identified 239 jobs that can be transferred to field centres; the rest of the cuts will have to come from voluntary resignations and layoffs, with more recently hired employees facing the highest likelihood of losing their jobs. A final plan for the reductions, which are to be distributed evenly among the agency's programme offices, is expected early next month.

Goldin has long believed that NASA headquarters should be smaller and leaner, in line with practice in industry. The agency had already planned to cut its Washington office to a little more than 1,000 people by 2000. But the size and pace of the new cuts took NASA employees - including many senior managers - by surprise.

As recently as three weeks ago, Goldin told a congressional committee that he was planning "no precipitous action" on the basis of lower White House budget projections, which call for NASA funding to drop from $\$ 13.8$ billion next year to $\$ 11.6$ billion in 2000. Jack Gibbons, head of the Office of Science and Technology, has also been playing down the importance of any projections beyond 1997 (see box, right).

But others say that NASA - and indeed every federal agency - should take the new numbers seriously. "They undoubtedly are real," says Lori Garver, executive director of the National Space Society, and a member of NASA's advisory council. Garver says the council will be briefed this week on the longterm budget picture, expected to be grim.

Both the council and NASA's House of Representatives Appropriations Committee, which also meets this week, are expected to ask tough questions about the agency's ability to function with such a small headquarters staff. At a hearing last week, James Sensenbrenner (Republican, Wisconsin), who chairs NASA's authorization subcommittee in the House, continued to question whether the agency can still afford everything on its plate, given the reduced budget figures. This week, the House will release its own seven-year projections, expected to be even harsher to federal agencies.

Senator Barbara Mikulski, whose Maryland constituency includes the Goddard Space Flight Center, issued an angry statement in response to NASA's action, calling
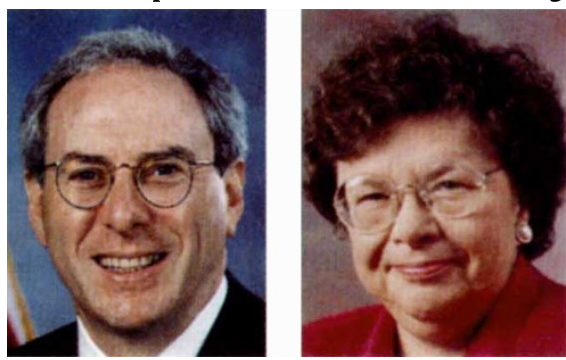

Head to head Goldin (left) and Mikulski disagree about the NASA proposals.

the proposed reductions "too much, too soon" and vowing to "stand sentry for the NASA budget in Congress" and to "take my fight all the way to the Oval Office if need be". But at the end of last week she was alone among Washington-area representatives in speaking out against the cuts. Unlike the agency's field centres, headquarters employees have no vocal champions in Congress.

Last week's decision has heightened fears at the centres that they, too, face even greater layoffs in the near future than they had been led to believe. And for headquarters employees - who had been told repeatedly that such deep cuts were not in prospect - morale has not been so low since the Challenger accident, said one observer. While the headquarters library began setting out literature on how to find a job, an unofficial "RIF [Reduction in Force] Watch" home page popped up on the World Wide Web, with a picture of a rocket spinning out of control and an acerbic quote: "Gee, we waited 'til the last minute, removed one out of every two components, and left the oldest ones in. I can't understand why it failed.

Tony Reichhardt

\section{Budget projections 'nearly meaningless'}

Washington. Jack Gibbons, President Bill Clinton's science adviser, has told US science lobbyists not to be too concerned with medium-term budget projections, and to concentrate instead on Congress's plans for cuts in the 1997 financial year, which starts on 1 October.

"The bottom line is that we are in the middle of a crisis this year and this month," Gibbons told the annual science policy symposium of the American Association for the Advancement of Science (AAAS) in Washington last week. "I don't know what 2002 will bring - neither does the Congress, neither does AAAS."

Gibbons was responding to an assessment by the AAAS of the Clinton administration's own budget proposals which had pointed out that the proposals would result in cuts in the science budget by 12 per cent by the year 2002 , with very sharp cuts during 1998-2000 (see Nature 380, 572; 1996).

Administration officials have repeatedly sought to play down the significance of their figures for the so-called 'outyears', and Gibbons told the AAAS that "the numbers and assumptions" behind the projections "border on the nearly meaningless".

"I'll be happy to have a debate over the 'out-years' when we know more about them," Gibbons said. Focusing on the situation for the fiscal year 1997, he added: "I want to point out the differences between President Clinton's commitment to science, and the seeming disdain some in Congress display for the increasing knowledge base that research makes possible - differences all too easily obscured by our obsession with numbers on a ledger sheet."

But the power of the ledger sheet was all too apparent on the day he spoke, when NASA announced hundreds of compulsory redundancies at its headquarters (see above), after struggling for years to avoid such redundancies.

Furthermore, physics lobbyists at last week's AAAS meeting said that the Department of Energy is already drawing up its 1998 budget proposals on the basis of the medium-term projections in the Clinton budget.

These projections include an 8 per cent cut in the \$1-billion general sciences budget at the energy department, which funds most particle and nuclear physics in the United States. A senior department official confirmed that it was planning around these projections, but said this did not necessarily mean that the projections would be implemented.

A statement issued by Gibbons in direct response to the AAAS assessment pointed out that Clinton has called for increases in science and technology funding for four years in a row. "The best way to predict the future is to look at what we have done in the past," said the statement, adding that the AAAS appeared to have underestimated future research and development budgets by assuming that cuts in federal agencies will hit all programmes equally hard.

Colin Macilwain 